Annals of Warsaw University of Life Sciences - SGGW

Land Reclamation No 48 (3), 2016: 267-284

(Ann. Warsaw Univ. of Life Sci. - SGGW, Land Reclam. 48 (3), 2016)

\title{
The effect of purified sewage discharge from a sewage treatment plant on the physicochemical state of water in the receiver
}

\author{
WŁODZIMIERZ KANOWNIK, AGNIESZKA POLICHT-LATAWIEC, \\ MAGDALENA WIŚNIOS \\ Department of Land Reclamation and Environmental Development, University of Agriculture in Krakow
}

\begin{abstract}
The effect of purified sewage discharge from a sewage treatment plant on the physicochemical state of water in the receiver. The paper presents changes in the contents of physicochemical indices of the Sudół stream water caused by a discharge of purified municipal sewage from a small mechanical-biological treatment plant with throughput of $300 \mathrm{~m}^{3} \cdot \mathrm{d}^{-1}$ and a population equivalent (p.e.) $-1,250$ people. The discharge of purified sewage caused a worsening of the stream water quality. Most of the studied indices values increased in water below the treatment plant. Almost a 100-fold increase in ammonium nitrogen, 17-fold increase in phosphate concentrations and 12-fold raise in $\mathrm{BOD}_{5}$ concentrations were registered. Due to high values of these indices, the water physicochemical state was below good. Statistical analysis revealed a considerable effect of the purified sewage discharge on the stream water physicochemical state. A statistically significant increase in 10 indices values $\left(\mathrm{BOD}_{5}, \mathrm{COD}-\mathrm{Mn}\right.$, EC, TDS, $\mathrm{Cl}^{-}, \mathrm{Na}^{+}, \mathrm{K}^{+}, \mathrm{PO}_{4}{ }^{3-}, \mathrm{N}_{-} \mathrm{NH}_{4}{ }^{+}$and $\mathrm{N}-\mathrm{NO}_{2}$ ) as well as significant decline in the degree of water saturation with oxygen were noted below the sewage treatment plant. On the other hand, no statistically significant differences between the water indices values were registered between the measurement points localised 150 and $1,000 \mathrm{~m}$ below the purified sewage discharge. It evidences a slow process of the stream water self-purification caused by an excessive loading with pollutants originating from the purified sewage discharge.
\end{abstract}

Key words: water quality, sewage discharge, pollutants, environmental monitoring

\section{INTRODUCTION}

Proper management of water resources and their quantitative and qualitative protection are the major objectives of the European Union Framework Water Directive, which obliges the member states to reach a good state of waters (WHO 1993, Council Directive 2000/60/EC). Therefore, conducting the research focused on the effect of purified sewage on water quality in receivers is one of many tasks which must be realized to fulfil the Accession Treaty obligations (Kałek and Piaskowski 2010), the way to utilize the forming sewage sludge for energy generation (Werle and Wilk 2010, Roati et al. 2012, Szaflik et al. 2014) and as a secondary product for lawn fertilization in the city areas (Bilgili and Acikgoz 2005, da Silva et al. 2014, Grabowski et al. 2015). The main issue, in compliance with the main assumptions of the European Union water policy, is sustainable development of the member countries in the area of political, economic and social activities at simultaneous maintaining the environmental balance and durability of basic biological processes. According to the water law, the area of Poland has 
been divided into water regions and basin areas which were characterized with reference to the effect of human activities (Domagała et al. 2010, Kanownik and Policht-Latawiec 2015) and economic analysis of water use in view of water services costs (Council Directive 2000/60/EC). It has been forecasted, that establishing the permissible values of pollutant emission and environmental standards of their quality will lead to a reduction of pollution at its source (Filus 2008, Sadecka et al. 2010, Jelić et al. 2011, Coppens et al. 2015).

The changes of water quality in a receiver caused by purified sewage discharge to the surface waters is a worldwide problem (Cotman et al. 2001, Graham et al. 2010, Scanes 2011, Policht-Latawiec 2012, Innaa et al. 2014, Makowska 2014). Water pollution is to great extend caused by biogenic substances, which penetrate to the aquatic environment with sewage (Jóźwiakowski and Marzec 2008, Panno et al. 2008, Neverova-Dziopak and Cierlikowska 2014, Karczmarczyk 2016). The assessment of the state of water and sewage management is made in order to indicate the influence of sewage drainage from treatment plants on surface water bodies (Piekutin 2008, Królak et al. 2011, Bueno et al. 2012, Kumar et al. 2012, Batkowski 2014).

Sewage discharge from small treatment plants below 2,000 population equivalent (p.e.) may negatively affect surface water management and protection. Treatment plants should prevent pollution and degradation of receiver waters, protect and improve the state of aquatic ecosystems to achieve the highest quality state, therefore ensuring that the requirements of the Council Direc- tive 91/271/EEC and the Framework Water Directive 2000/60/EC.

The aim of the paper was determining the changes of water quality in the Sudól stream caused by the discharge of purified sewage from the mechanical-biological treatment plant with a 1,250 p.e. situated in Trojadyn village near Krakow. The paper discussed the values of pollution indices determined in the sewage discharged from the treatment plant and analysed its impact on the change of physicochemical state of water in the receiver. Moreover, the water quality was assessed and the conditions of fish life in the Sudół stream above and below the place of purified sewage discharge.

\section{MATERIAL AND METHODS}

Hydrochemical analyses were conducted in the Sudół stream catchment from March 2012 to February 2013. Water was sampled on 12 dates (once a month) in four measurement points (Fig. 1) situated: $50 \mathrm{~m}$ (point 1) and $150 \mathrm{~m}$ (point 2) above the collector outlet and about $1,000 \mathrm{~m}$ (point 3) below the purified sewage discharge (ISO 5667-6), as well as directly from the collector draining purified sewage to the receiver (point D). The water $\mathrm{pH}$ was measured on site using CP-104 pH meter, electrolytic conductivity with CC-102 conductometer, dissolved oxygen concentration and the degree of water saturation with oxygen by means of CO-411 oxygen meter and total amount of dissolved solids was measured in water using TDS meter (Hach Lange). In the laboratory, total suspended solids were determined by drying and weighing 


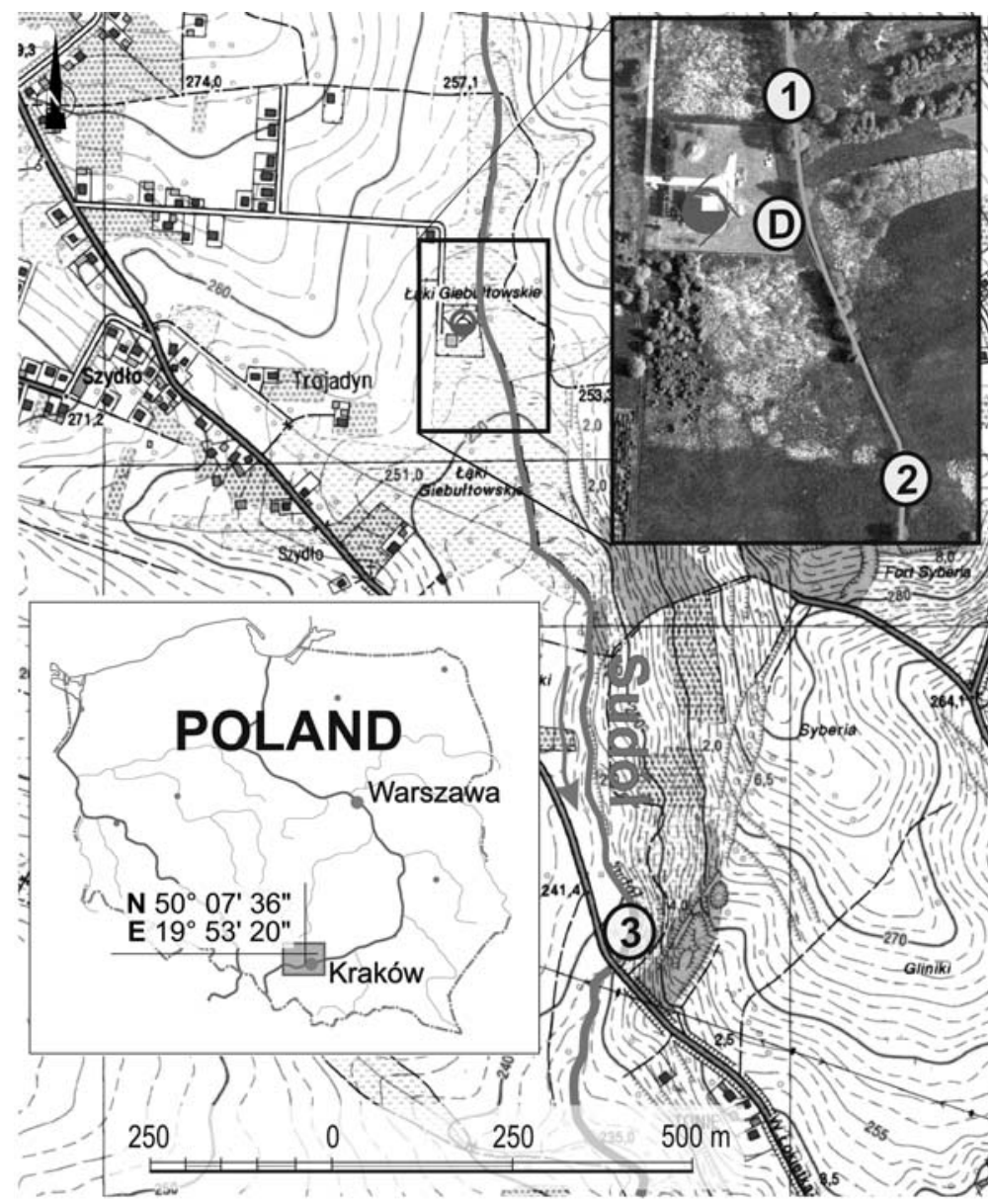

(1) (2)(3) measurement-control point of Sudół stream

(D) sewage discharge

sewage treatment plant

FIGURE 1. Location of measurement-control points

method, concentrations of $\mathrm{Ca}^{2+}, \mathrm{Mg}^{2+}$, $\mathrm{Na}^{+}, \mathrm{K}^{+}, \mathrm{Fe}\left(\mathrm{Fe}^{2+}\right.$ and $\left.\mathrm{Fe}^{3+}\right)$ and $\mathrm{Mn}^{2+}$ ions using atomic absorption spectrometry (ASA) on Unicam SOLAAR 969 spectrometer. The five-day biochemical oxygen demand $\left(\mathrm{BOD}_{5}\right)$ was assessed using Winkler's method and chemical oxygen demand by titration method in $\mathrm{KMnO}_{4}$. The concentrations of ammoni- um nitrogen $\left(\mathrm{N}-\mathrm{NH}_{4}^{+}\right)$, nitrite $\left(\mathrm{N}-\mathrm{NO}_{2}^{-}\right)$ and nitrate $\left(\mathrm{N}^{-\mathrm{NO}_{3}}{ }^{-}\right)$nitrogen, phosphates $\left(\mathrm{PO}_{4}{ }^{3-}\right)$ and chlorides $\left(\mathrm{Cl}^{-}\right)$were assessed by flow colorimetry analysis on FIAstar 5000 apparatus and sulphates $\left(\mathrm{SO}_{4}{ }^{2-}\right)$ by precipitation method (Regulation... 2013).

The values of pollutant indices in purified sewage were compared with the 
highest values permissible in compliance with the Regulation of the Minister of the Environment on the conditions which must be fulfilled when discharging sewage to waters or to the soil and on the substances particularly harmful to the aquatic environment (Regulation... 2014b). The Sudół stream water quality class in the measurement points was determined according to the Regulation of the Minister of the Environment on the method of classification of the ecological state, ecological potential and chemical state of uniform parts of surface waters (Regulation... 2014a). The functional values of the stream water were evaluated by comparing the assessment results with the value admissible for fish life in natural conditions (Regulation... 2002).

Descriptive statistics were used for elaboration of results, the minimum and maximum values were determined, as well as the arithmetic mean, standard deviation and median for individual indices. A statistical inference about the significance of indices values differences between the measurement points was conducted using the Kruskal-Wallis non-parametric test on the significance level $\alpha=0.05$ in Statistica 12. After determining the significance of differences between the compared groups, analysis for the pairs of measurement points was conducted for selected water quality indices using Mann-Whitney U-test on the significance level $\alpha=0.05$. The non-parametric tests were chosen because of the lack of normal distribution for the majority of analysed indices, in compliance with the results of the Shapiro-Wilk test and the lack of the homogeneity of variance determined by the Fisher-Snedecor test (Buda and Jarynowski 2010). More- over, the cluster analysis was conducted for the measurement control points and physicochemical indices within the individual points, aimed at grouping the objects (points or indices) so that the objects within each of the identified group were similar to each other, but possibly the least similar to the objects of the other groups, according to the rule of internal similarity and external dissimilarity. If there are clusters of objects similar to each other, the structure may be presented as separate branches on a hierarchical tree (tree diagram). Estimation of the distance between groups was conducted using Ward's method, which bases on the analysis of variance and aims at minimizing any two cluster sum of squares (Stanisz 2007).

According to the administrative division of the country, the Sudó stream catchment is situated in the Małopolskie voivodship, Krakow county, on the border of Wielka Wieś and Zielonki villages and Prądnik Biały quarter in the north part of Krakow. According to Kanownik et al. (2012), the highest percentage (43\%), i.e. about 637 ha of the Sudól stream catchment is covered by grasslands dispersed over the whole area, whereas the smallest $0.2 \%$ ( 2 ha) are grounds under water. Arable lands cover almost $30 \%$ and orchards constitute $6 \%$ of the total catchment area. The built up and transport area cover about 220 ha. The Sudół stream is the third order watercourse, a right bank tributary to the Praqdnik river, flowing into the Vistula. The source of the stream is situated at $288 \mathrm{~m}$ a.s.l. The watercourse flows through the Łąki Giebultowskie area, Tonie village and in its final, about $1.5 \mathrm{~km}$ stretch through housing areas of 
Krakow. Its total length is $8,840 \mathrm{~m}$ and average bottom slope 1.01 .

The sewage treatment plant was constructed according to the Local Space Management Plan for Wielka Wieś commune, in Trojadyn village in the area of so-called Łąki Giebułtowskie (Giebultowskie Meadows) - Figure 1. The building of the sewage treatment plant covers about $168 \mathrm{~m}^{2}$ of usable area. Sewage is channeled to the treatment plant through the gravity sewer system from about 2,150 inhabitants and additionally sewage is supplied by septic tankers from the local hotel and schools situated in the commune. The mechanical-biological sewage treatment plant uses Finnish technology, according to which sewage purification occurs through a prolonged aeration in activated sludge chamber, where the conditions for simultaneous stabilization of the excessive sludge are provided. The biological technology of sewage cleaning bases on removal of nitrogen and phosphorous compounds. Removal of nitrogen compounds is carried on in the activate sludge chamber during a basic process occurring at the initial phase, in the anoxic part of the chamber. Phosphorus compounds are removed both at the initial phase of purification and during the process of simultaneous precipitation by means of iron salts. The treatment plant comprises the following appliances: step filter, grit chambers, aeration chamber, secondary settlement tank, secondary sludge stabilization chamber and secondary sludge press. About $11 \mathrm{Mg}$ of sludge in conversion to dry mass is generated per year (Water law permit on the assessment of the environmental impact of a sewage treatment plant in Wielka Wieś 2010).
The collector draining purified sewage is located at km 2+010 of the Sudó1 stream course, on its right bank. The catchment area to the collector outlet is $3.56 \mathrm{~km}^{2}$. In the discharge area the stream banks are not reinforced and the stream cross section is of trapezoidal shape. Average annual water flow in this place is $S S Q=0.037 \mathrm{~m}^{3} \cdot \mathrm{s}^{-1}$, whereas medium low $S B Q=0.008 \mathrm{~m}^{3} \cdot \mathrm{s}^{-1}$. The amount of drained purified sewage is $Q=300 \mathrm{~m}^{3} \cdot \mathrm{day}^{-1}$ and $Q_{\text {max.h }}=25 \mathrm{~m}^{3} \cdot \mathrm{s}^{-1}$, which constitutes respectively 9.4 and $18.8 \%$ of average water flow in the stream.

\section{RESULTS AND DISCUSSION}

The analysis of pollution indices results in purified municipal sewage in point $\mathrm{D}$, as determined in the regulation on the conditions which must be fulfilled when discharging sewage to waters or to the soil, revealed exceeded highest values for total suspended solids and $\mathrm{BOD}_{5}$ (Table 1). Total suspended solids concentration only on one date exceeded the value of $50 \mathrm{mg} \cdot \mathrm{dm}^{-3}$ and the five-day biochemical oxygen demand $\left(\mathrm{BOD}_{5}\right)$ was above the highest admissible value $\left(40 \mathrm{mg} \cdot \mathrm{dm}^{-3}\right)$ on three dates. Since at the number of samples from 8 to 16 the regulation allows 2 samples in which the indices may exceed the highest admissible values, in the purified sewage from the treatment plant in Trojadyn village, only $\mathrm{BOD}_{5}$ value did not meet the conditions required when discharging sewage to waters. Total suspended solids concentration ranged from 1 to $152 \mathrm{mg} \cdot \mathrm{dm}^{-3}$, with the average value on the level of $20.6 \mathrm{mg} \cdot \mathrm{dm}^{-3}$. Value $\mathrm{BOD}_{5}$ ranged from 1.1 to $112 \mathrm{mg} \mathrm{O}_{2} \cdot \mathrm{dm}^{-3}$ and its average 
TABLE 1. Statistical parameters describing the values of pollution indices in purified sewage and the highest admissible values

\begin{tabular}{|c|c|c|c|c|}
\hline Indicator & Range & Average & $\begin{array}{l}\text { Standard } \\
\text { deviation }\end{array}$ & $\begin{array}{l}\text { The maximum } \\
\text { allowable values } \\
\text { stated in Ministry } \\
\text { Regulation (2014a) }\end{array}$ \\
\hline Temperature $\left({ }^{\circ} \mathrm{C}\right)$ & $8.8-20.2$ & 15.1 & 3.8 & 35 \\
\hline Reaction $\mathrm{pH}$ & $7.2-7.8$ & 7.5 & 0.21 & $6.5-9$ \\
\hline Total Suspended Solids (TSS) $\left(\mathrm{mg} \cdot \mathrm{dm}^{-3}\right)$ & $1.0-152$ & 20.6 & 45 & 50 \\
\hline Dissolved Oxygen (DO) $\left(\mathrm{mg} \mathrm{O}_{2} \cdot \mathrm{dm}^{-3}\right)$ & $2.6-15.7$ & 7.2 & 3.4 & - \\
\hline $\begin{array}{l}\text { Biochemical Oxygen Demand }\left(\mathrm{BOD}_{5}\right) \\
\left(\mathrm{mg} \mathrm{O}_{2} \cdot \mathrm{dm}^{-3}\right)\end{array}$ & $1.4-112$ & 38 & 40 & 40 \\
\hline $\begin{array}{l}\text { Chemical Oxygen Demand (COD-Mn) } \\
\left(\mathrm{mg} \mathrm{O}_{2} \cdot \mathrm{dm}^{-3}\right)\end{array}$ & $1.5-21.8$ & 13.3 & 7.2 & - \\
\hline Oxygen Saturation Degree (OSD) (\%) & $29-141$ & 75 & 30 & - \\
\hline Electrolytic Conductivity $(\mathrm{EC})\left(\mu \mathrm{S} \cdot \mathrm{cm}^{-1}\right)$ & $693-1,686$ & 1,205 & 334 & - \\
\hline Total Dissolved Solids (TDS) $\left(\mathrm{mg} \cdot \mathrm{dm}^{-3}\right)$ & $522-1,050$ & 813 & 141 & - \\
\hline $\mathrm{SO}_{4}^{2-}\left(\mathrm{mg} \cdot \mathrm{dm}^{-3}\right)$ & 71-309 & 110 & 67 & 500 \\
\hline $\mathrm{Cl}^{-}\left(\mathrm{mg} \cdot \mathrm{dm}^{-3}\right)$ & $38-337$ & 213 & 82 & 1,000 \\
\hline $\mathrm{Ca}^{2+}\left(\mathrm{mg} \cdot \mathrm{dm}^{-3}\right)$ & $70-128$ & 92 & 17 & - \\
\hline $\mathrm{Mg}^{2+}\left(\mathrm{mg} \cdot \mathrm{dm}^{-3}\right)$ & $11-25$ & 17 & 4 & - \\
\hline $\mathrm{Na}^{+}\left(\mathrm{mg} \cdot \mathrm{dm}^{-3}\right)$ & $13-275$ & 140 & 76 & 800 \\
\hline $\mathrm{K}^{+}\left(\mathrm{mg} \cdot \mathrm{dm}^{-3}\right)$ & $2.7-30.1$ & 16.8 & 7.2 & 80 \\
\hline $\mathrm{PO}_{4}{ }^{3-}\left(\mathrm{mg} \cdot \mathrm{dm}^{-3}\right)$ & $0.35-29.5$ & 8.5 & 9.0 & - \\
\hline $\mathrm{N}-\mathrm{NH}_{4}{ }^{+}\left(\mathrm{mg} \cdot \mathrm{dm}^{-3}\right)$ & $0.76-76.8$ & 21.3 & 21.8 & 10 \\
\hline $\mathrm{N}-\mathrm{NO}_{2}{ }^{-}\left(\mathrm{mg} \cdot \mathrm{dm}^{-3}\right)$ & $0.015-0.89$ & 0.30 & 0.33 & 1 \\
\hline $\mathrm{N}-\mathrm{NO}_{3}{ }^{-}\left(\mathrm{mg} \cdot \mathrm{dm}^{-3}\right)$ & $0.0-3.9$ & 1.0 & 1.2 & 30 \\
\hline $\mathrm{Fe}\left(\mathrm{mg} \cdot \mathrm{dm}^{-3}\right)$ & $0.12-2.70$ & 1.03 & 0.70 & 10 \\
\hline $\mathrm{Mn}^{2+}\left(\mathrm{mg} \cdot \mathrm{dm}^{-3}\right)$ & $0.07-0.36$ & 0.16 & 0.09 & - \\
\hline
\end{tabular}

value was $38 \mathrm{mg} \mathrm{O}_{2} \cdot \mathrm{dm}^{-3}$. The maximum total suspended solids concentration registered during the investigations $\left(152 \mathrm{mg} \cdot \mathrm{dm}^{-3}\right)$ and $\mathrm{BOD}_{5}$ value $(112 \mathrm{mg}$ $\mathrm{O}_{2} \cdot \mathrm{dm}^{-3}$ ) were almost threefold higher than the highest permissible value according to the ministrial regulation.

The extended physicochemical analysis of the sewage including substances particularly harmful to the aquatic environment conducted in compliance with the guidelines for industrial sewage revealed, that during the period of the research, the sewage temperature ranged from 8.8 to $20.2^{\circ} \mathrm{C}$ and its $\mathrm{pH}$ was neutral within the $\mathrm{pH}$ range 7.2-7.8. These values did not exceed the value permissible by the Minister of the Environment regulation of 2014. The highest sulphates $\left(309 \mathrm{mg} \cdot \mathrm{dm}^{-3}\right)$ and chlorides $\left(337 \mathrm{mg} \cdot \mathrm{dm}^{-3}\right.$ ) concentrations were lower than the admissible values (Regu- 
lation... 2014b). On the other hand, ammonium nitrogen concentration (mean 21.3 and maximum $76.8 \mathrm{mg} \cdot \mathrm{dm}^{-3}$ ) respectively 2 and 7.5 times exceeded the permissible values stated in the regulation in force. The maximum concentration of nitrite nitrogen $\left(0.89 \mathrm{mg} \cdot \mathrm{dm}^{-3}\right)$ was slightly lower than the permissible value $\left(1 \mathrm{mg} \cdot \mathrm{dm}^{-3}\right)$. The other values of the analysed pollution indices were much lower than the values stated by the minister regulation (Regulation... 2014b).

The physicochemical state of the Sudó stream water above the sewage treatment plant (point 1) was below good, due to mean value of phosphates exceeding by $0.03 \mathrm{mg} \cdot \mathrm{dm}^{-3}$ the value permissible for the water quality class II. Average concentration of dissolved solids and nitrate nitrogen allowed to classify water to the class II (Regulation... 2014a). The other 12 indices considered in the assessment of the physicochemical composition were in the quality class I (Table 2). Increase in a majority of the analysed water indices concentrations occurred below the purified sewage discharge. The highest increase in pollutant concentrations was observed $150 \mathrm{~m}$ below the sewage discharge to the receiver (point 2). It was on average: $11.78 \mathrm{mg} \cdot \mathrm{dm}^{-3}$ for ammonium nitrogen (100-fold increase in concentration), $5.36 \mathrm{mg} \cdot \mathrm{dm}^{-3}$ for phosphates (17-fold), for $\mathrm{BOD}_{5}-28.4 \mathrm{mg} \mathrm{O} \cdot \mathrm{dm}^{-3}$ (12-fold), for total suspended solids $-23.8 \mathrm{mg} \cdot \mathrm{dm}^{-3}$ (8-fold), for nitrite nitrogen $-0.14 \mathrm{mg} \cdot \mathrm{dm}^{-3}(7.5$-fold $)$, in case of sodium $-54 \mathrm{mg} \cdot \mathrm{dm}^{-3}$ and potassium - $5.7 \mathrm{mg} \cdot \mathrm{dm}^{-3}$ (4-fold), for COD-Mn $6.4 \mathrm{mg} \mathrm{O} \mathrm{O}_{2} \cdot \mathrm{dm}^{-3}$ and chlorides $70 \mathrm{mg} \cdot \mathrm{dm}^{-3}$ (2.5-fold increase). Due to the waters drained from the treatment plant, also water quality class in the Sudó 1 stream changed. In both measurement points (points 2 and 3), the stream water did not meet the requirements of the water quality class II because of $\mathrm{BOD}_{5}$, $\mathrm{PO}_{4}{ }^{3-}$ and $\mathrm{N}-\mathrm{NH}_{4}{ }^{+}$values. The analysis of physicochemical indices concentrations in the water collected $1,000 \mathrm{~m}$ below the sewage treatment plant (point 3) allowed to classify ten of them to the class I and two to the class II (Regulation... 2014a).

The research conducted by Królak et al. (2011) on the effect of mechanical-biological sewage treatment plant on water quality revealed that purified sewage discharged from the treatment plant in Wisznica and Piszczac villages had a slight influence on the increase in nitrate, and ammonium ions and $\mathrm{EC}$, and did not cause a change in water quality class in the receivers (Zielawa and Lutnia watercourses). The hydrochemical research carried on the Sudół Dominikański stream demonstrated an on-going pollution of its water by the sewage discharges from the treatment plant in Węgrzce commune. The load of disposed sewage proved too large in relation to the water flow in the stream, which led to a worsening of the water in the watercourse (Kanownik and Rajda 2008). Also, the investigations conducted by Kowalik et al. (2015) on the Bren river revealed a considerable effect of purified sewage discharge from a modernised mechanical-biological sewage treatment plant on the water quality in the receiver. The discharge caused an increase in the values of 12 of the 17 analysed physicochemical indices in the Bren river, of which in 8 cases the relationships were statistically significant. It was found that $\mathrm{BOD}_{5}$ values and ammonium nitrogen con- 


\begin{tabular}{|c|c|c|c|c|c|c|c|c|c|c|c|c|c|c|c|c|c|c|}
\hline \multirow{2}{*}{\multicolumn{2}{|c|}{ 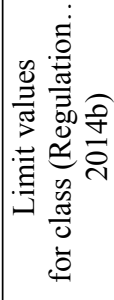 }} & $=$ & $\underset{\mathrm{V}}{\stackrel{J}{\mathrm{~N}}}$ & $\hat{b}$ & $\begin{array}{l}\stackrel{8}{n} \\
\mathrm{VI}\end{array}$ & $\stackrel{n}{\wedge}$ & $\begin{array}{l}6 \\
\mathrm{VI}\end{array}$ & $\frac{\mathrm{N}}{\mathrm{Vl}}$ & 1 & $\frac{8}{8}$ & $\begin{array}{l}\stackrel{8}{\infty} \\
\text { VI }\end{array}$ & $\begin{array}{l}0 \\
\stackrel{2}{n} \\
\mathrm{VI}\end{array}$ & $\begin{array}{l}8 \\
\text { D } \\
\text { VI }\end{array}$ & 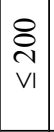 & $\begin{array}{l}\varrho \\
\varrho \\
\mathrm{VI}\end{array}$ & 1 & 1 & $\begin{array}{l}\vec{n} \\
0 \\
\text { VI }\end{array}$ \\
\hline & & -1 & VI & $\left|\begin{array}{l}n \\
\infty \\
b\end{array}\right|$ & 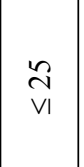 & $\hat{\wedge}$ & $\mathrm{MI}$ & $\begin{array}{l}\sigma \\
\mathrm{Vl}\end{array}$ & 1 & $\frac{8}{8}$ & $\begin{array}{l}8 \\
\stackrel{\circ}{n} \\
\text { VI }\end{array}$ & $\frac{i}{\mathrm{n}}$ & 尺े & $\begin{array}{l}\stackrel{\Xi}{\varrho} \\
\mathrm{VI}\end{array}$ & 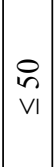 & 1 & 1 & $\begin{array}{c}\text { Na } \\
\text { VI }\end{array}$ \\
\hline \multirow{6}{*}{ 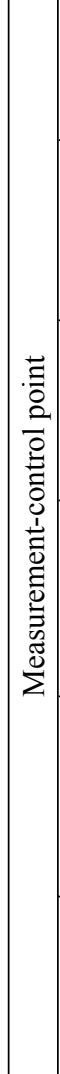 } & $m$ & \multirow{3}{*}{$\begin{array}{l}8 \\
8 \\
\pi \\
0 \\
⿱ 亠 乂\end{array}$} & $\begin{array}{l}i n \\
i n\end{array}$ & $\mid$\begin{tabular}{l|}
$\tilde{\sigma}$ \\
0 \\
$\infty$
\end{tabular} & $\begin{array}{l}\stackrel{\varpi}{0} \\
\stackrel{\Omega}{\sim}\end{array}$ & $\begin{array}{l}\underset{\infty}{\infty} \\
\infty \\
\infty\end{array}$ & 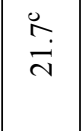 & $\stackrel{0}{\hat{0}}$ & $\infty$ & $\stackrel{\frac{\pi}{5}}{\hat{\sigma}}$ & 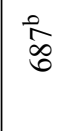 & જ̆ & $\stackrel{\widetilde{0}}{\varrho}$ & జ̋ & $\stackrel{\infty}{\infty}$ & in & $\hat{\sigma}$ & 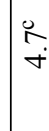 \\
\hline & $\sim$ & & 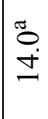 & 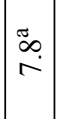 & $\stackrel{\text { ำ }}{\stackrel{\sim}{\sim}}$ & $\stackrel{\tilde{i}}{\infty}$ & $\frac{0}{m}$ & $\stackrel{\infty}{\infty}$ & 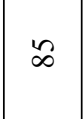 & $\stackrel{\sigma}{\sigma}$ & $\stackrel{\mathbb{6}}{6}$ & నू & $\stackrel{\widetilde{\Omega}}{\cong}$ & $\tilde{\sigma}$ & $\stackrel{\Xi}{I}$ & $\dddot{2}$ & $\stackrel{\infty}{\sim}$ & $\begin{array}{l}i \\
\text { in }\end{array}$ \\
\hline & - & & $\stackrel{a}{\stackrel{2}{a}}$ & $\begin{array}{l}\frac{\pi}{\infty} \\
\infty\end{array}$ & $\stackrel{\pi}{\stackrel{\sigma}{\sigma}}$ & $\stackrel{\square}{ٌ}$ & $\begin{array}{l}\tilde{J} \\
\text { i }\end{array}$ & $\stackrel{\pi}{\stackrel{\sigma}{*}}$ & 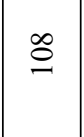 & $\stackrel{\pi}{6}$ & $\begin{array}{l}\text { in } \\
\text { nn }\end{array}$ & $\ddot{n}$ & $\tilde{n}$ & $\begin{array}{l}\infty \\
\infty \\
\infty\end{array}$ & $\stackrel{\infty}{\infty}$ & 2 & $\vec{i}$ & 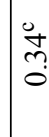 \\
\hline & $m$ & & $\begin{array}{l}\vec{a} \\
\mathfrak{a} \\
\tilde{n} \\
\sim\end{array}$ & $\left|\begin{array}{c}\nabla \\
\infty \\
1 \\
\check{r} \\
\sim\end{array}\right|$ & $\begin{array}{l}n \\
n \\
o \\
1 \\
n \\
0\end{array}$ & $\begin{array}{l}n \\
\stackrel{n}{0} \\
\vdots \\
0 \\
0\end{array}$ & $\begin{array}{l}\exists \\
\stackrel{1}{I} \\
=\end{array}$ & $\begin{array}{l}\infty \\
\stackrel{\sim}{\sim} \\
\grave{0} \\
\stackrel{+}{+}\end{array}$ & $\frac{\nexists}{d}$ & $\begin{array}{l}\stackrel{2}{2} \\
\stackrel{2}{n} \\
\frac{1}{7}\end{array}$ & 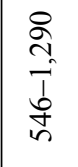 & $\begin{array}{l}\underset{\infty}{d} \\
\mathfrak{d} \\
\stackrel{2}{2}\end{array}$ & $\begin{array}{l}0 \\
i \\
i \\
\infty \\
\infty\end{array}$ & $\begin{array}{l}\vec{J} \\
\\
\infty \\
\infty\end{array}$ & 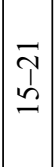 & $\mid \begin{array}{c}n \\
n \\
n \\
n\end{array}$ & $\begin{array}{l}n \\
n \\
n \\
b \\
i \\
i\end{array}$ & $\begin{array}{l}0 \\
\sim \\
n \\
n \\
0\end{array}$ \\
\hline & $\sim$ & 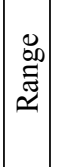 & 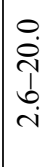 & $\mid \begin{array}{c}\tau \\
\infty \\
0 \\
b \\
r\end{array}$ & $\begin{array}{l}\stackrel{0}{\Xi} \\
\stackrel{1}{\prime}\end{array}$ & $\frac{0}{\stackrel{1}{n}}$ & 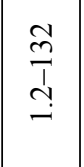 & 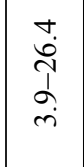 & $\frac{\stackrel{J}{I}}{\underset{J}{J}}$ & $\begin{array}{l}\hat{\infty} \\
\stackrel{n}{n} \\
\stackrel{1}{n}\end{array}$ & $\begin{array}{l}0 \\
\infty \\
\infty \\
\infty \\
\dot{1}\end{array}$ & 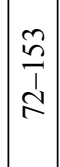 & $\begin{array}{l}\widetilde{O} \\
\sim \\
\sim \\
\sim \\
\sim\end{array}$ & 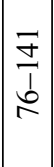 & 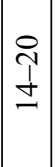 & $\begin{array}{l}\infty \\
\infty \\
1 \\
\simeq\end{array}$ & 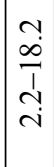 & 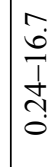 \\
\hline & - & & 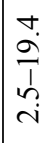 & $\left|\begin{array}{c}a \\
\infty \\
1 \\
r\end{array}\right|$ & $\frac{\hat{T}}{0}$ & 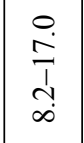 & $\begin{array}{l}\circ \\
\dot{I} \\
o \\
0\end{array}$ & $\begin{array}{l}\stackrel{0}{0} \\
\stackrel{1}{0} \\
i\end{array}$ & $\frac{\stackrel{P}{+}}{1}$ & $\begin{array}{l}\text { } \\
\hat{\jmath} \\
\stackrel{0}{0}\end{array}$ & $\begin{array}{l}0 \\
\infty \\
0 \\
0 \\
0 \\
\infty\end{array}$ & $\left|\begin{array}{l}\infty \\
n \\
\eta \\
n \\
n\end{array}\right|$ & $\begin{array}{l}n \\
0 \\
0 \\
2 \\
m\end{array}$ & $\begin{array}{l}\infty \\
m \\
\grave{1} \\
+\end{array}$ & 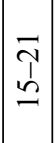 & $\begin{array}{l}\stackrel{\sim}{\tau} \\
\stackrel{2}{\sim}\end{array}$ & $\mid \begin{array}{l}\infty \\
i \\
\hat{T} \\
\hat{o}\end{array}$ & $\begin{array}{l}0 \\
\infty \\
0 \\
1 \\
\\
0\end{array}$ \\
\hline & 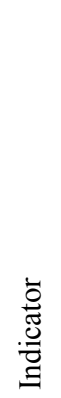 & & 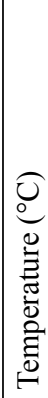 & 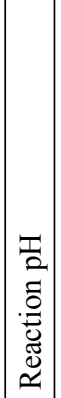 & 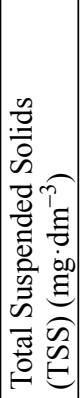 & 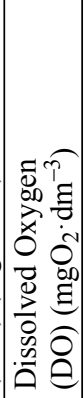 & 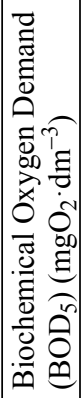 & 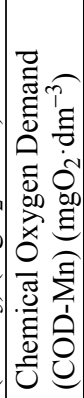 & 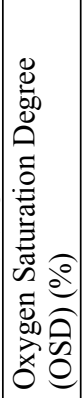 & 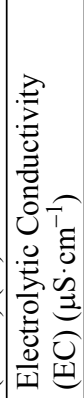 & 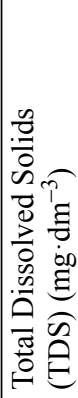 & 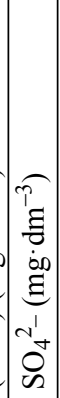 & 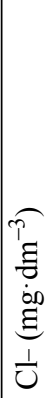 & 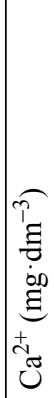 & 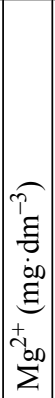 & 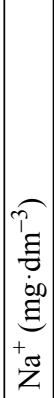 & 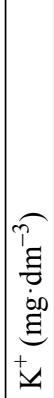 & 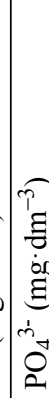 \\
\hline
\end{tabular}




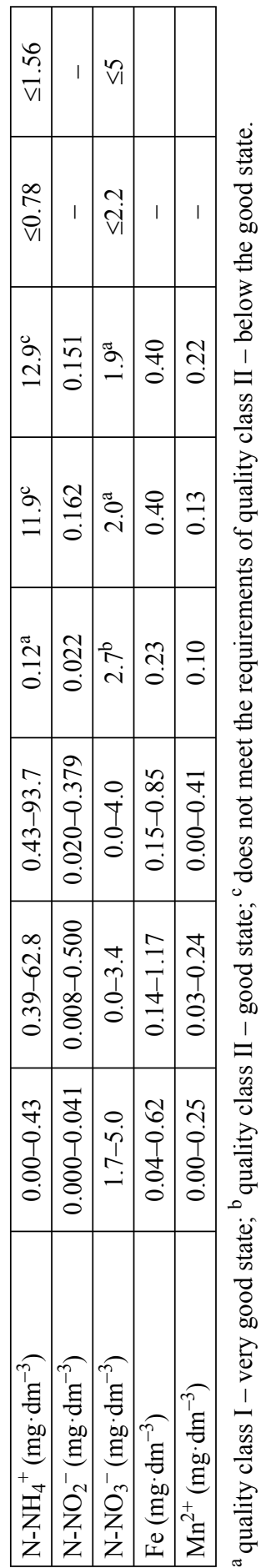

centrations affected a change of water physicochemical state from a very good to good, and in case of phosphates from very good to below good.

A high level of ammonium and total nitrogen caused by industrial and municipal sewage discharge was also noted in the Yellow River in China (Chen et al. 2004). Results of the investigations on Mamasin reservoir water in Turkey prove the increase in nitrates and ammonium nitrogen due to industrial and domestic sewage discharge (Elhatip and Güllü 2005). The research was carried out from 2003 to 2009 in Missouri, US on the impact of purified sewage on water quality in the Blue River flowing on the border to Johnson Country and Kansas. The environmental conditions were determined by means of collected data analysis and comparison of the water quality indices concentrations above and below the collector outlet. The changes in the lower course of the river were the highest during low discharges, when the purified sewage constituted about $20 \%$ of the channel flow. The water samples immediately below the collector revealed high concentrations of ammonium, nitrate and phosphate ions both before and after the treatment plant modernisation. It is most probably due to non-optimised biological removal of these compounds. During the period of normal flows the concentrations were between 4 to 15 times higher than in the water samples above the collector. Despite the fact that the treatment plant modernisation improved the quality of sewage discharged to the Blue River, the process still had a negative influence on the water quality and contributed to increase in the primary production (Graham et al. 2010). In 
Europe, the integrated attitude towards the assessment of the purified sewage impact on the forecast of ecological hazard was adopted among others in Slovenia, where the water in the Krka river, to which purified municipal and industrial sewage is discharged from city treatment plants, was analysed. The sewage subjected to biological sewage treatment contained high concentrations of organic nitrogen, ammonia, phosphates and zinc. During the summer period an excessive water saturation with dissolved oxygen was registered. Inhibition of water selfpurification process was observed owing to excessive concentrations of nitrogen, phosphorus and zinc in the water samples analysed in the points most distanced from the collector outlets. Results of the investigations indicated a neces- sity to diminish the emission of pollutant loads supplied so far in the purified sewage to improve water quality in the river and intensify the self-purification process (Cotman et al. 2001).

Water of the Sudół stream was assessed as a natural environment of the cyprinid and salmonid fish life. On the basis of seven analysed indices (temperature, total suspended solids, $\mathrm{pH}$, dissolved oxygen, biochemical oxygen demand, ammonium nitrogen, nitrite) it was determined that the water in all points did not meet requirements for the salmonid and cyprinid fish species. In point 1 (above the sewage discharge) only $20 \%$ of water samples fulfilled the requirements for both the salmonid and cyprinid fish due to the nitrite concentrations, whereas $73 \%$ due to $\mathrm{BOD}_{5}$ content

TABLE 3. Usability of stream water as a natural environment for fish

\begin{tabular}{|c|c|c|c|c|c|c|c|c|}
\hline \multirow{3}{*}{ Indicator } & \multicolumn{6}{|c|}{$\begin{array}{l}\text { Frequency of index values } \\
\text { ( } \% \text { of samples) in normative range } \\
\text { for a given fish category }\end{array}$} & \multicolumn{2}{|c|}{$\begin{array}{l}\text { Values required } \\
\text { for inland waters as } \\
\text { environment for fish } \\
\text { (Regulation... 2002) }\end{array}$} \\
\hline & \multicolumn{3}{|c|}{ salmonids } & \multicolumn{3}{|c|}{ cyprynids } & \multirow[b]{2}{*}{ salmonids } & \multirow[b]{2}{*}{ cyprynids } \\
\hline & ت. & $\stackrel{\sim}{\stackrel{2}{\Xi}}$ & $\stackrel{m}{\stackrel{m}{*}}$ & . & $\stackrel{\sim}{\stackrel{2}{\Xi}}$ & $\stackrel{n}{\stackrel{n}{\Xi}}$ & & \\
\hline Temperature $\left({ }^{\circ} \mathrm{C}\right)$ & 100 & 100 & 100 & 100 & 100 & 100 & $21.5^{\mathrm{a}}$ & $28.0^{\mathrm{a}}$ \\
\hline Reaction $\mathrm{pH}$ & 100 & 100 & 100 & 100 & 100 & 100 & \multicolumn{2}{|c|}{$6-9^{c}$} \\
\hline $\begin{array}{l}\text { Total Suspended Solids } \\
(\mathrm{TSS})\left(\mathrm{mg} \cdot \mathrm{dm}^{-3}\right)\end{array}$ & $3.4^{\mathrm{c}}$ & $27.2^{\mathrm{c}, \mathrm{d}}$ & $13^{\mathrm{c}}$ & $3.4^{\mathrm{c}}$ & $27.2^{\mathrm{c}, \mathrm{d}}$ & $13^{\mathrm{c}}$ & \multicolumn{2}{|c|}{$\begin{array}{l}\text { average annual value } \\
\leq 25\end{array}$} \\
\hline \multirow{2}{*}{$\begin{array}{l}\text { Dissolved Oxygen } \\
\text { (DO) }\left(\mathrm{mg} \mathrm{O}_{2} \cdot \mathrm{dm}^{-3}\right)\end{array}$} & 82 & 55 & $45^{\mathrm{d}}$ & 100 & 73 & 64 & $50 \% \geq 9$ & $50 \% \geq 8$ \\
\hline & 100 & $73^{d}$ & $73^{\mathrm{d}}$ & 100 & $82^{\mathrm{d}}$ & $82^{\mathrm{d}}$ & $100 \% \geq 7$ & $100 \% \geq 5$ \\
\hline $\begin{array}{l}\text { Biochemical Oxygen } \\
\left.\text { Demand (BOD })_{5}\right) \\
\left(\mathrm{mg} \mathrm{O}_{2} \cdot \mathrm{dm}^{-3}\right)\end{array}$ & $73^{\mathrm{d}}$ & $27^{\mathrm{d}}$ & $20^{\mathrm{d}}$ & 100 & $36^{\mathrm{d}}$ & $20^{\mathrm{d}}$ & $\leq 3^{b}$ & $\leq 6^{\mathrm{b}}$ \\
\hline $\mathrm{N}-\mathrm{NH}_{4}^{+}\left(\mathrm{mg} \cdot \mathrm{dm}^{-3}\right)$ & 100 & $10^{\mathrm{d}}$ & $20^{\mathrm{d}}$ & 100 & $10^{\mathrm{d}}$ & $20^{\mathrm{d}}$ & $\leq 0.78^{b}$ & $\leq 0.78^{\mathrm{b}}$ \\
\hline $\mathrm{NO}_{2}^{-}\left(\mathrm{mg} \cdot \mathrm{dm}^{-3}\right)$ & $20^{\mathrm{d}}$ & $0^{\mathrm{d}}$ & $0^{\mathrm{d}}$ & $20^{\mathrm{d}}$ & $10^{\mathrm{d}}$ & $0^{\mathrm{d}}$ & $\leq 0.01^{\mathrm{b}}$ & $\leq 0.03^{\mathrm{b}}$ \\
\hline
\end{tabular}

${ }^{\mathrm{a}}$ For $98 \%$ of samples; ${ }^{\mathrm{b}}$ for $95 \%$ of samples; ${ }^{\mathrm{c}}$ average value; ${ }^{\mathrm{d}}$ requirements not fulfilled. 
for the salmonids (Table 3 ). On the other hand, below the sewage discharge (points 2 and 3) water in the Sudół stream did not meet the requirements for the natural habit of either the salmonid or cyprinid fish species because of a low concentration of dissolved oxygen, high biochemical oxygen demand $\left(\mathrm{BOD}_{5}\right)$ and high concentrations of ammonium nitrogen and nitrites; moreover, in point 2 average annual concentration of total suspended solids exceeded $25 \mathrm{mg} \cdot \mathrm{dm}^{-3}$ (Regulation... 2002). In all measurement points only the temperature and water $\mathrm{pH}$ were appropriate for the habitat the salmonid or cyprinid fish species.

The statistical analysis conducted using Kruskal-Wallis non-parametric test for the measurement points revealed that the water quality indices differ significantly among the points in case of a group of the indices characterizing oxygen conditions, salinity (except the phosphates, calcium and magnesium) water $\mathrm{pH}$, biogenic substances and metals $\mathrm{Fe}$ and Mn. The test probability for these indices was lower than 0.05 (Table 4). The analysis of the differences of water indices for the pairs of points on the Sudól stream performed using Mann-Whitney U-test revealed that between points1 and 2 , significantly higher values were registered in point 2 (below the discharge) for $\mathrm{BOD}_{5}, \mathrm{COD}-\mathrm{Mn}, \mathrm{EC}, \mathrm{TDS}, \mathrm{Cl}^{-} \mathrm{Na}^{+}$, $\mathrm{K}^{+}, \mathrm{PO}_{4}{ }^{3-}, \mathrm{N}_{-} \mathrm{NH}_{4}{ }^{+}, \mathrm{N}-\mathrm{NO}_{2}{ }^{-}$and signi-

TABLE 4. Comparison of physicochemical indices values between measurement points using Kruska-Wallis non-parametric test

\begin{tabular}{|c|c|c|c|c|c|c|}
\hline \multirow{3}{*}{ Indicator } & \multicolumn{4}{|c|}{ Measurement-control point } & \multicolumn{2}{|c|}{$\begin{array}{c}\text { Results of } \\
\text { Kruskal-Wallis test }\end{array}$} \\
\hline & 1 & $\mathrm{D}$ & 2 & 3 & \multirow{2}{*}{ test value } & \multirow{2}{*}{$\begin{array}{c}\text { probabil- } \\
\text { ity test }\end{array}$} \\
\hline & \multicolumn{4}{|c|}{ median } & & \\
\hline Temperature $\left({ }^{\circ} \mathrm{C}\right)$ & 11.6 & 13.8 & 12.7 & 12.6 & 2.16 & 0.54 \\
\hline Reaction $\mathrm{pH}$ & $8.1^{\mathrm{a}}$ & $7.5^{\mathrm{a}}$ & $7.8^{\mathrm{a}}$ & $8.0^{\mathrm{a}}$ & $19.7^{\mathrm{a}}$ & $<0.01^{\mathrm{a}}$ \\
\hline $\begin{array}{l}\text { Total Suspended Solids } \\
(\mathrm{TSS})\left(\mathrm{mg} \cdot \mathrm{dm}^{-3}\right)\end{array}$ & 3.0 & 3.8 & 4.3 & 2.8 & 2.37 & 0.50 \\
\hline $\begin{array}{l}\text { Dissolved Oxygen } \\
\text { (DO) }\left(\mathrm{mgO}_{2} \cdot \mathrm{dm}^{-3}\right)\end{array}$ & $10.5^{\mathrm{a}}$ & $7.2^{\mathrm{a}}$ & $9.0^{\mathrm{a}}$ & $8.6^{\mathrm{a}}$ & $10.8^{\mathrm{a}}$ & $0.01^{\mathrm{a}}$ \\
\hline $\begin{array}{l}\text { Biochemical Oxygen Demand } \\
\left(\mathrm{BOD}_{5}\right)\left(\mathrm{mgO}_{2} \cdot \mathrm{dm}^{-3}\right)\end{array}$ & $2.6^{\mathrm{a}}$ & $25.2^{\mathrm{a}}$ & $13.2^{\mathrm{a}}$ & $10.8^{\mathrm{a}}$ & $13.2^{\mathrm{a}}$ & $<0.01^{\mathrm{a}}$ \\
\hline $\begin{array}{l}\text { Chemical Oxygen Demand } \\
(\mathrm{COD}-\mathrm{Mn})\left(\mathrm{mgO}_{2} \cdot \mathrm{dm}^{-3}\right)\end{array}$ & $4.8^{\mathrm{a}}$ & $14.4^{\mathrm{a}}$ & $9.4^{\mathrm{a}}$ & $10.5^{\mathrm{a}}$ & $13.5^{\mathrm{a}}$ & $<0.01^{\mathrm{a}}$ \\
\hline $\begin{array}{l}\text { Oxygen Saturation Degree } \\
(\mathrm{OSD})(\%)\end{array}$ & $106^{\mathrm{a}}$ & $77^{\mathrm{a}}$ & $93^{\mathrm{a}}$ & $97^{\mathrm{a}}$ & $11.1^{\mathrm{a}}$ & $0.01^{\mathrm{a}}$ \\
\hline $\begin{array}{l}\text { Electrolytic Conductivity } \\
(\mathrm{EC})\left(\mu \mathrm{S} \cdot \mathrm{cm}^{-1}\right)\end{array}$ & $736^{\mathrm{a}}$ & $1,232^{\mathrm{a}}$ & $878^{\mathrm{a}}$ & $889^{\mathrm{a}}$ & $11.4^{\mathrm{a}}$ & $<0.01^{\mathrm{a}}$ \\
\hline $\begin{array}{l}\text { Total Dissolved Solids } \\
(\mathrm{TDS})\left(\mathrm{mg} \cdot \mathrm{dm}^{-3}\right)\end{array}$ & $560^{\mathrm{a}}$ & $806^{\mathrm{a}}$ & $684^{\mathrm{a}}$ & $628^{\mathrm{a}}$ & $18.4^{\mathrm{a}}$ & $<0.01^{\mathrm{a}}$ \\
\hline $\mathrm{SO}_{4}{ }^{2}-\left(\mathrm{mg} \cdot \mathrm{dm}^{-3}\right)$ & 80 & 95 & 87 & 95 & 4.6 & 0.20 \\
\hline $\mathrm{Cl}-\left(\mathrm{mg} \cdot \mathrm{dm}^{-3}\right)$ & $53^{\mathrm{a}}$ & $215^{\mathrm{a}}$ & $80^{\mathrm{a}}$ & $81^{\mathrm{a}}$ & $22.4^{\mathrm{a}}$ & $<0.01^{\mathrm{a}}$ \\
\hline $\mathrm{Ca}^{2+}\left(\mathrm{mg} \cdot \mathrm{dm}^{-3}\right)$ & 85 & 89 & 91 & 90 & 0.52 & 0.92 \\
\hline
\end{tabular}


TABLE 4 cont.

\begin{tabular}{|c|c|c|c|c|c|c|}
\hline \multirow{3}{*}{ Indicator } & \multicolumn{4}{|c|}{ Measurement-control point } & \multicolumn{2}{|c|}{$\begin{array}{c}\text { Results of } \\
\text { Kruskal-Wallis test }\end{array}$} \\
\hline & 1 & $\mathrm{D}$ & 2 & 3 & \multirow{2}{*}{ test value } & \multirow{2}{*}{$\begin{array}{c}\text { probabil- } \\
\text { ity test }\end{array}$} \\
\hline & \multicolumn{4}{|c|}{ median } & & \\
\hline $\mathrm{Mg}^{2+}\left(\mathrm{mg} \cdot \mathrm{dm}^{-3}\right)$ & 18 & 16 & 18 & 18 & 2.1 & 0.54 \\
\hline $\mathrm{Na}^{+}\left(\mathrm{mg} \cdot \mathrm{dm}^{-3}\right)$ & $19^{\mathrm{a}}$ & $127^{\mathrm{a}}$ & $48^{\mathrm{a}}$ & $42^{\mathrm{a}}$ & $23^{\mathrm{a}}$ & $<0.01^{\mathrm{a}}$ \\
\hline $\mathrm{K}^{+}\left(\mathrm{mg} \cdot \mathrm{dm}^{-3}\right)$ & $2.1^{\mathrm{a}}$ & $16.9^{\mathrm{a}}$ & $6.1^{\mathrm{a}}$ & $5.7^{\mathrm{a}}$ & $28^{\mathrm{a}}$ & $<0.01^{\mathrm{a}}$ \\
\hline $\mathrm{PO}_{4}{ }^{3-}\left(\mathrm{mg} \cdot \mathrm{dm}^{-3}\right)$ & $0.24^{\mathrm{a}}$ & $6.0^{\mathrm{a}}$ & $3.1^{\mathrm{a}}$ & $2.1^{\mathrm{a}}$ & $16.8^{\mathrm{a}}$ & $<0.01^{\mathrm{a}}$ \\
\hline $\mathrm{N}-\mathrm{NH}_{4}{ }^{+}\left(\mathrm{mg} \cdot \mathrm{dm}^{-3}\right)$ & $0.09^{\mathrm{a}}$ & $15.1^{\mathrm{a}}$ & $4.0^{\mathrm{a}}$ & $3.4^{\mathrm{a}}$ & $24.3^{\mathrm{a}}$ & $<0.01^{\mathrm{a}}$ \\
\hline $\mathrm{N}-\mathrm{NO}_{2}-\left(\mathrm{mg} \cdot \mathrm{dm}^{-3}\right)$ & $0.024^{\mathrm{a}}$ & $0.111^{\mathrm{a}}$ & $0.086^{\mathrm{a}}$ & $0.120^{\mathrm{a}}$ & $12.9^{\mathrm{a}}$ & $<0.01^{\mathrm{a}}$ \\
\hline $\mathrm{N}-\mathrm{NO}_{3}{ }^{-}\left(\mathrm{mg} \cdot \mathrm{dm}^{-3}\right)$ & $2.5^{\mathrm{a}}$ & $0.8^{\mathrm{a}}$ & $2.2^{\mathrm{a}}$ & $2.0^{\mathrm{a}}$ & $10.2^{\mathrm{a}}$ & $0.02^{\mathrm{a}}$ \\
\hline $\mathrm{Fe}\left(\mathrm{mg} \cdot \mathrm{dm}^{-3}\right)$ & $0.21^{\mathrm{a}}$ & $0.96^{\mathrm{a}}$ & $0.26^{\mathrm{a}}$ & $0.34^{\mathrm{a}}$ & $14.6^{\mathrm{a}}$ & $<0.01^{\mathrm{a}}$ \\
\hline $\mathrm{Mn}^{2+}\left(\mathrm{mg} \cdot \mathrm{dm}^{-3}\right)$ & $0.11^{\mathrm{a}}$ & $0.14^{\mathrm{a}}$ & $0.11^{\mathrm{a}}$ & $0.21^{\mathrm{a}}$ & $8.9^{\mathrm{a}}$ & $0.03^{\mathrm{a}}$ \\
\hline
\end{tabular}

${ }^{\mathrm{a}}$ The statistical value that the differences are statistically important on the level $\alpha=0.05$.

fi-antly lower degree of oxygen saturation (Table 5).

Lewandowska-Robak et al. (2011) while assessing the impact of mechanical-biological sewage treatment plant with increased nutrients removal on water quality in the Kicz stream in Tuchola, the largest city of Bory Tucholskie determined, that in result of the purified sewage discharge the concentrations of chlorides, nitrates, nitrites and $\mathrm{BOD}_{5}$ raised significantly in the receiver water.

On the other hand, along almost $1,000 \mathrm{~m}$ stream stretch below sewage discharge no statistical differences were found among the physicochemical water indices between point 2 and 3, which indicated the inhibition of water self-purification processes resulting from its pollution. The fact was also confirmed by the cluster analysis conducted for standardized values of physicochemical indices, on the basis of which it was stated that the drainage water and water in the Sudół below the discharge form one group, whereas water in the Sudół above the discharge forms a separate cluster (Fig. 2).

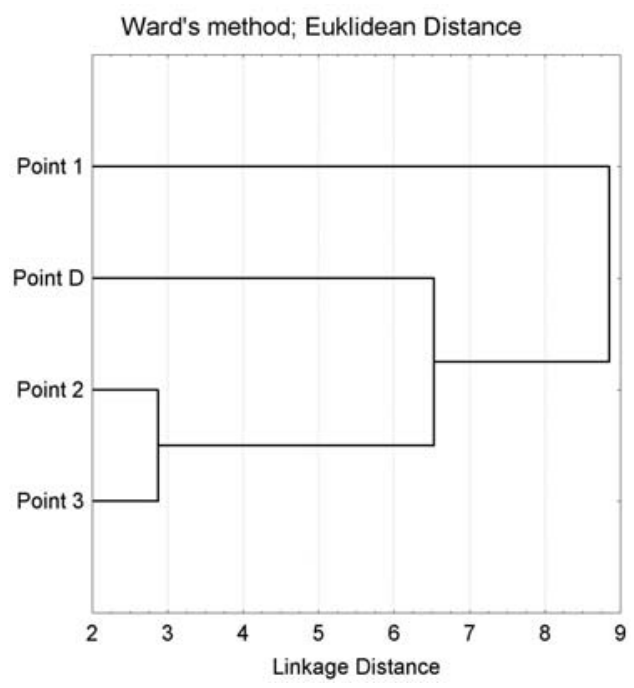

FIGURE 2. Cluster analysis (dendrogram) similarity of physical and chemical indicators of water measurement and control 


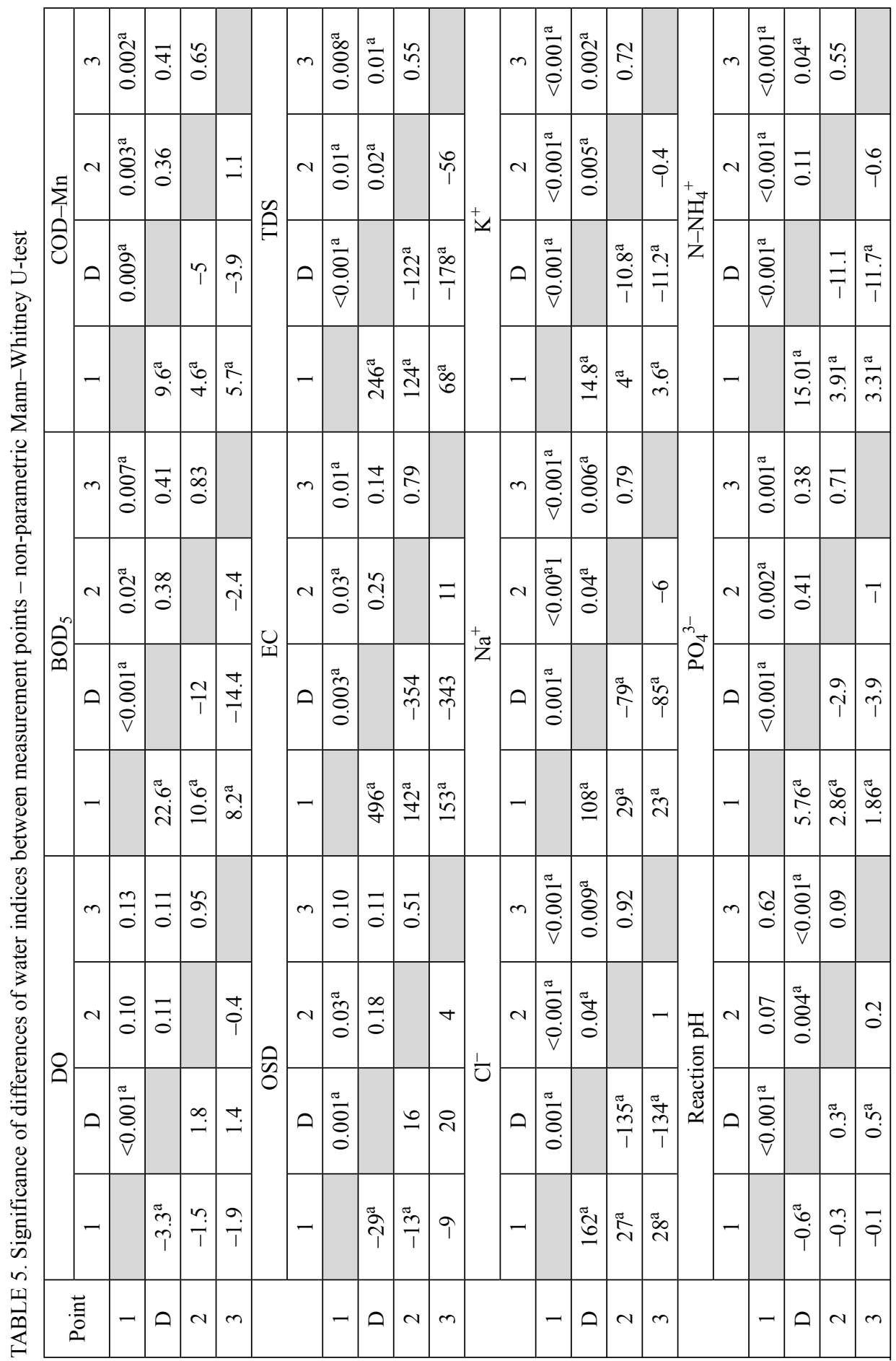




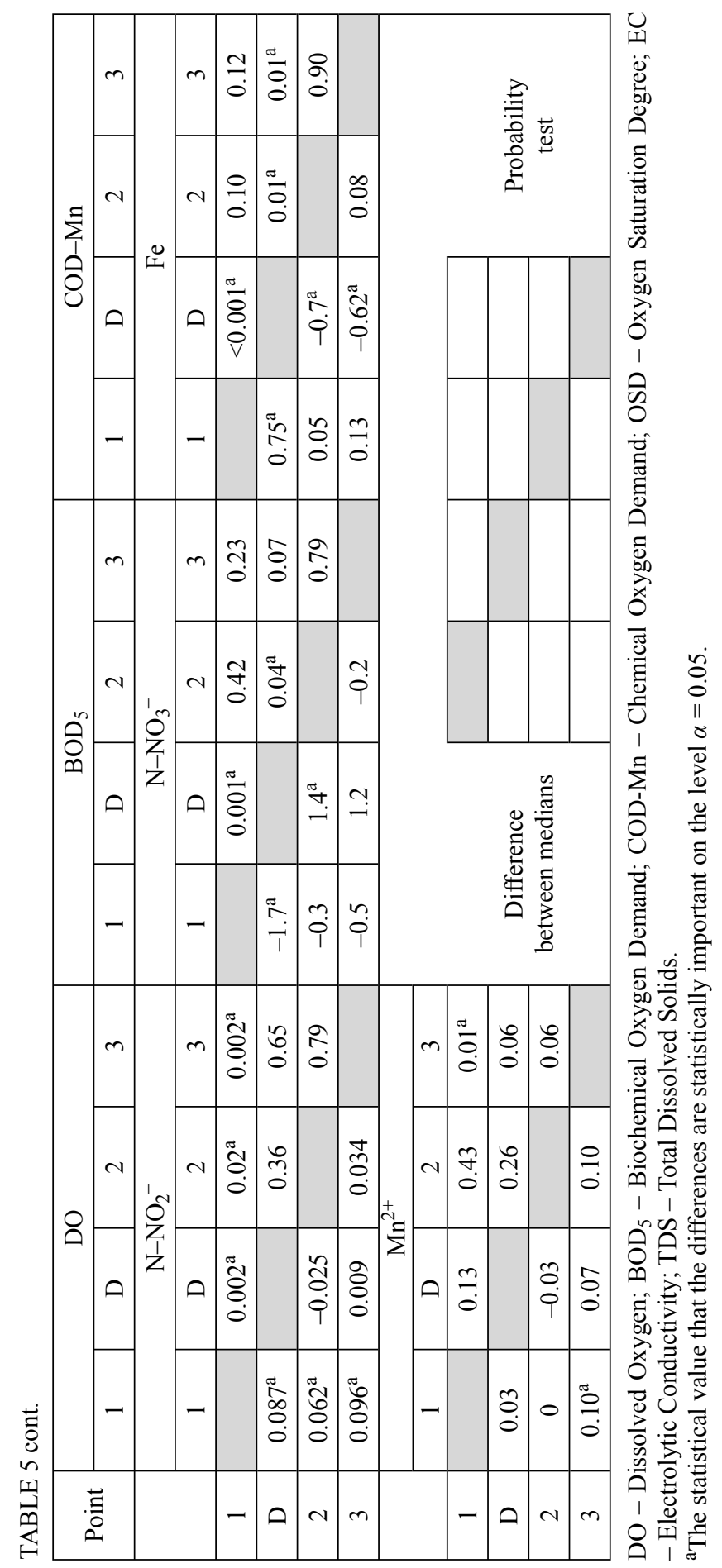




\section{CONCLUSIONS}

The analysis of pollutants in the purified municipal sewage revealed that $\mathrm{BOD}_{5}$ value did not fulfil the required conditions which must be observed when discharging sewage into waters or to the soil. Moreover, high amount of phosphates and ammonium nitrates in the discharged sewage, although not covered by obligatory monitoring, poses a hazard to the flora and fauna in the Sudó 1 stream bed.

The Sudó analysed stretch did not meet the requirements for the quality class II and its physicochemical state was below good. Above the purified sewage discharge only one index (phosphates) slightly exceeded the limit value. On the other hand, below the discharge collector a considerable deterioration of the stream water quality occurred. Beside phosphate concentrations, also ammonium nitrogen and $\mathrm{BOD}_{5}$ concentrations exceeded the limit value for the water quality class II.

Along the whole investigated Sudó stretch, water did not meet the requirements for the natural habitat of the salmonid (Salmo spp.) family, the Coregonidae family (Coregonus) or Thymallus thymallus fish, the cyprinid fish, or other fish species, like Esox lucius, Perca fluviatilis or Anguilla anguilla because of high nitrite concentrations. Discharge of purified sewage into the stream caused a decrease in the dissolved oxygen in water, increase in biochemical oxygen demand and ammonium nitrate concentrations, which added to a worsening of fish life conditions.

Statistical analysis of physicochemical indices in the stream waters revealed that below the discharge of purified sewage, the values of 11 out of 21 analysed indices changed statistically significantly. It evidences a considerable effect of the discharged sewage on water physicochemical state and disturbance of the biological functioning of the ecosystem. A big pollutant load reduced the process of the stream water self-purification. Below the discharge from the sewage treatment plants (point 2), the water concentration of ammonium nitrogen increased 100 times, $\mathrm{BOD}_{5}$ value and phosphate concentration over 10 times and total suspended solids and nitrite nitrogen over 5 times.

In order to reduce the negative effect of the sewage treatment plant and therefore improve the physicochemical and ecological state of water in the Sudół stream, technological measures connected with the modernisation of the treatment plant should be implemented aiming at the increasing the efficiency of nitrogen and phosphorus reduction in the sewage.

\section{REFERENCES}

BATKOWSKI B. 2014: Ocena i monitoring efektywności działania oczyszczalni ścieków „Czajka” oraz jej wpływ na środowisko naturalne [Assessment and monitoring of WWTP „Czajka” efficiency and its environmental impact]. Gaz, Woda i Technika Sanitarna 4, 159-164 [Engl. summ.].

BILGILI U., ACIKGOZ E. 2005: Year-round nitrogen fertilization effects on growth and quality of sports turf mixtures. J. Plant Nutr. 28, 299-307.

BUDA A., JARYNOWSKI A. 2010: Lifetime of correlations and its applications. $1,5-21$. 
BUENO M.J.M., GOMEZ M.J., HERRERA S., HERNANDO M.D., AGÜERA A., FERNÁNDEZ-ALBA A.R. 2012: Occurrence and persistence of organic emerging contaminants and priority pollutants in five sewage treatment plants of Spain: Two years pilot survey monitoring. Environ. Pollut. 164, 267-273.

CHEN J., HE D., ZHANG N., CUI S. 2004: Characteristics of and human influences on nitrogen contamination in Yellow River System, China. Environ. Monit. Assess. 93, 125-138.

COPPENS L.J.C., van GILS J.A.G., ter LAAK T.L., RATERMAN B.W., van WEZEL A.P. 2015: Towards spatially smart abatement of human pharmaceuticals in surface waters: Defining impact of sewage treatment plants on susceptible functions. Water Res. 81, 356-365.

COTMAN M., ZAGORC-KONCAN J., DROIC A. 2001: Study of impacts of treated wastewater to the Krka river, Slovenia. Water Sci. Technol. 40 (6), 47-54.

Council Directive 91/271/ EEC of 21 May 1991 concerning urban waste-water treatment. Official Journal of the European Communities, Belgium, 21 May 1991.

Council Directive 2000/60/EC of the European Parliament and of the Council establishing a framework for Community action in the field of water police. OJ L 327, 21.12.2000.

da SILVA J.A., ZANETTE M.M., CECHIN I. 2014: The influence of municipal treated wastewater on morpho-physiological characteristics of Eucalyptus plants. $\mathrm{Wa}$ ter, Air, Soil Poll. 225, 2130.

DOMAGẢŁA J., CZZERINIAWSKI R., PILECKA-RAPACZ M. 2010: Zagrożenia antropogeniczne wód zlewni Drawy [Anthropogenic environmental threat of Drawa drainage]. Infrastr. Ekol. Ter. Wiejs. 9, 157-168 [Engl. summ.].

ELHATIP H., GÜLLÜ Ö. 2005: Influences of wastewater discharges on the water quality of Mamasin dam watershed in Aksaray, Central Anatolian part of Turkey. Environ. Geol. 48, 829-834.
FILUS J. 2008: Enterprise Europe Network. Raport Izby Przemysłowo-Handlowej w Krakowie [in Polish].

GRABOWSKI K., GŁOWACKA-GIL A., GRZEGORCZYK S., GRABOWSKA K. 2015: Utility values of extensive lawns fertilized with sewage sludge. Pol. J. Environ. Stud. 24 (5), 1959-1968.

GRAHAM J.L., STONE M.L., RASMUSSEN T.J., POULTON B.C. 2010: Effects of wastewater effluent discharge and treatment facility upgrades on environmental and biological conditions of the upper Blue River, Johnson County, Kansas and Jackson County, Missouri, January 2003 through March 2009: U.S. Geological Survey Scientific Investigations Report 2010 - 5248.

INNAA D., LESTER J.N., SCRIMSHAWB M.D., CARTMELL E. 2014: Speciation and fate of copper in sewage treatment works with and without tertiary treatment: The effect of return flows. Environ. Technol. 35 (1-4), 1-9.

ISO 5667-6:1997. Water quality. Sampling. Part 6: Guidance on sampling of rivers and Streams.

JELIĆ A., GROS M., GINEBREDA A., CESPEDES-SÁNCHEZ R., VENTURA F., PETROVIC M., BARCELO D. 2011: Occurrence, partition and removal of pharmaceuticals in sewage water and sludge during wastewater treatment. $\mathrm{Wa}$ ter Res. 45 (3), 1165-1176.

JÓŹWIAKOWSKI K., MARZEC M. 2008: Zmiany jakości wód $w$ odbiorniku ścieków [Changes of water quality in a sewage receiver]. Wodociagi-Kanalizacja 12, 28-30 [in Polish].

KAŁEK K., PIASKOWSKI K. 2010: Influence of wastewater treatment plant "Jamno" on receiving body of water quality. Forum Eksploatatora 3 (48), 44-50 [in Polish].

KANOWNIK W., KOWALIK T., BOGDAŁ A., OSTROWSKI K., RAJDA W. 2012: Quality and functional values of waters flowing away from catchment of small storage reservoirs planned in the area of 
Krakow. Publishing House of the University of Agriculture in Krakow, Kraków.

KANOWNIK W., POLICHT-LATAWIEC A. 2015: Changeability of oxygen and biogenic indices in waters flowing through the areas under various anthropopressure. Pol. J. Environ. Stud. 24 (4), 1633-1640.

KANOWNIK W., RAJDA W. 2008: Źródła zanieczyszczeń wód powierzchniowych w zlewni potoku Sudół Dominikański [Sources of surface water pollution in Sudol Dominikanski stream catchment]. Acta Sci. Pol. Form. Cir. 7 (2), 3-14 [Engl. summ.].

KARCZMARCZYK A. 2016: Hauled liquid waste as a pollutant of soils and waters in Poland. Ann. Warsaw Univ. Life Sci. - SGGW, Land Reclam. 48 (2), 111-122.

KOWALIK T., BOGDAŁ A., BOREK Ł., KOGUT A. 2015: The effect of treated sewage outflow from a modernized sewage treatment plant on water quality on the Breń river. J. Ecol. Eng. 16 (4), 96-102.

KRÓLAK E., KORYCIŃSKA M., DIADIK K., GODZIUK S. 2011: Czy lokalne oczyszczalnie ścieków wpływają na jakość wód w ich odbiornikach? [Do local sewage treatment plants influence the quality of water in sewage receiving rivers?]. Ochr. Środ. i Zasob. Natur. 48, 343-352 [Engl. summ.].

KUMAR K.R., SUMAN M., ARCHANA S. 2012: Water quality assessment of raw sewage and final treated water with special reference to Waste Water Treatment Plant Bhopal, MP, India. Res. J. Recent Sci. 1, 185-190.

LEWANDOWSKA-ROBAK M., GÓRSKI Ł., KOWALKOWSKI T., DABKOWSKA-NASKRĘT H., MIESZKOWSKA I. 2011: Wpływ ścieków oczyszczonych odprowadzanych z Oczyszczalni Ścieków w Tucholi na jakość wody w strudze Kicz [The influence of treated sewage discharged from wastewater treatment plant in Tuchola on water quality of Kicz stream]. Inżynieria i Ochrona Środowiska 14 (3), 209-221 [Engl. summ.].

MAKOWSKA M. 2014: Wpływ stopnia oczyszczania ścieków na jakość wód powierzchniowych [Wastewater treatment standard influence on the quality of surfaces water]. Gaz, Woda i Technika Sanitarna 2, 60-65 [Engl. summ.].

NEVEROVA-DZIOPAK E., CIERLIKOWSKA P. 2014: Wpływ modernizacji wybranej oczyszczalni ścieków na stan troficzny wód odbiornika [Impact of wastewater treatment plant modernization on trophic state of recipient]. Ochrona Środowiska 36 (2), 53-58 [Engl. summ.].

PANNO S.V., KELLY W.R., HACKLEY K.C., HWANG H., MARTINSEK A.T. 2008: Sources and fate of nitrate in the Illinois River Basin, Illinois. J. Hydrol. 359, 174-188.

PIEKUTIN J. 2008: Wpływ rozwoju gospodarczego na jakość wody powierzchniowej Narwi i jej dopływów w powiecie białostockim [Influence of development on quality of superfictial water in Podlasie district]. Infrastr. Ekol. Ter. Wiejs. 5, 31-40 [Engl. summ.].

POLICHT-LATAWIEC A. 2012: Effect of treated sewage on water quality in the receive waters. Acta Hort. et Regiotec. 15, 46-50.

ROATI C., FIORE S., RUFFINO B., MARCHESE F., NOVARINO D., ZANETTI M.C. 2012: Preliminary evaluation of the potential biogas production of food-processing industrial wastes. Am. J. Environ. Sci. 8 (3), 291-296.

Regulation of the Minister of the Environment dated 04 October 2002 on the requirements for inland waters which are fish habitat in natural conditions (Journal of Laws No. 176, item 1455).

Regulation of the Minister of the Environment dated 21 November 2013 on the forms and ways of monitoring uniform parts of surface and ground waters (Journal of Laws 2013, item 1558).

Regulation of the Minister of the Environment dated 22 October 2014 on the method of classification of the state of uniform parts of surface waters and environmental quality standards for priority substances (Journal of Laws 2014a, item 1482), 2014a. 
Regulation of the Minister of the Environment dated 18 November 2014 amending the regulation on the conditions which must be fulfilled when discharging sewage to waters or to the soil and on the substances particularly harmful to the aquatic environment (Journal of Laws 2014b, item 1800), 2014b.

SADECKA Z., SIECIECHOWICZ A., ZALEWSKA B. 2010: Ocena skuteczności oczyszczania ścieków w oczyszczalni w aspekcie odbiornika ścieków oczyszczonych [Assessment of the efficiency of sewage cleaning in respect of purified sewage receiver]. Forum Eksploatatora 6 (51), 62-65 [in Polish].

SCANES P.R. 2011: Environmental impact of deepwater discharge of sewage of Sydney. Mar. Pollut. Bull. 5, 38-42.

STANISZ A. 2007: Przystępny kurs statystyki z zastosowaniem STATISTICA PL na przykładach $\mathrm{z}$ medycyny. Analizy wielowymiarowe [Simple course in statistics using STATISTICA PL on examples from medicine. Multivariate Analyses]. StatSoft Poland, Krakow [in Polish].

SZAFLIK W., IŻEWSKA A., DOMINOWSKA M. 2014: Chemical energy balance of digested sludge in sewage treatment plant Pomorzany in Szczecin. Rocz. Ochr. Sr. $16,16-33$.

WERLE S., WILK R.K. 2010: A review of methods for the thermal utilization of sewage sludge: The Polish perspective. Renew. Energ. 35, 1914-1919.

WHO, 2011: Guidelines for drinking-water quality. $4^{\text {th }}$ edn. (NLM classification: WA 675).

Streszczenie: Wplyw zrzutu oczyszczonych ścieków z oczyszczalni na stan fizykochemiczny wody $w$ odbiorniku. W pracy przedstawiono wpływ zrzutu oczyszczonych ścieków z mechanicznobiologicznej oczyszczalni o RLM poniżej 2000 na stan fizykochemiczny wody w odbiorniku (potok Sudół). Badania hydrochemiczne prowadzono od marca 2012 roku do lutego 2013 roku Próby wody pobrano w 12 terminach (raz na miesiąc) w czterech punktach pomiarowo-kontrolnych: $50 \mathrm{~m}$ powyżej ujścia kolektora, 150 i 1000 m poniżej zrzutu ścieków oczyszczonych oraz bezpośrednio z kolektora odprowadzającego ścieki oczyszczone do odbiornika. Wnioskowanie statystyczne o istotności różnic wartości wskaźników między punktami pomiarowo-kontrolnymi przeprowadzono nieparametrycznym testem Kruskala-Wallisa oraz U Manna-Whitneya. Na badanej długości potoku Sudół wody nie spełniały wymogów II klasy jakości, stan fizykochemiczny wody był poniżej dobrego. Powyżej zrzutu ścieków oczyszczonych tylko stężenie fosforanów nieznacznie przekraczało wartość graniczną dla II klasy. Poniżej $(150$ i 1000 m) kolektora zrzutowego jakość wody w badanym potoku uległa pogorszeniu $\mathrm{z}$ powodu wzrostu wartości BZT $_{5}$ i ChZT-Mn oraz stężeń azotu amonowego. Zrzut ścieków oczyszczonych spowodował wzrost stężenia większości badanych wskaźników jakościowych w wodzie potoku Sudół. Tuż poniżej zrzutu z oczyszczalni, w wodzie potoku wzrosło stężenie azotu amonowego 100-krotnie, wartość $\mathrm{BZT}_{5}$ i stężenie fosforanów ponad 10-krotnie oraz stężenie zawiesina ogólna i azotu azotynowego ponad 5-krotnie. Woda na badanym odcinku potoku Sudół nie spełniała wymagań dla naturalnego środowiska życia ryb łososiowatych oraz karpiowatych ze względu na wysokie stężenia azotynów. Analiza statystyczna wskaźników fizykochemicznych wody potoku Sudół wykazała, że poniżej zrzutu ścieków oczyszczonych statystycznie istotnie zmieniły się wartości 11 wskaźników fizykochemicznych z spośród 21 badanych. Aby ograniczyć negatywne oddziaływanie oczyszczalni ścieków, a tym samym poprawić stan fizykochemiczny i ekologiczny wody w potoku Sudół, należy zwiększyć skuteczność redukcji azotu w ściekach.

\section{MS received April 2016}

\section{Authors' address:}

Włodzimierz Kanownik, Agnieszka Policht-Latawiec, Magdalena Wiśnios

Katedra Melioracji i Kształtowania Środowiska Wydział Inżynierii Środowiska i Geodezji Uniwersytet Rolniczy w Krakowie al. Mickiewicza 24-28, 30-059 Kraków

Poland

e-mail: rmkanown@cyf-kr.edu.pl, a.policht@ur.krakow.pl 